\title{
Strengthening Character Education in Elementary School
}

\author{
L. J. Ananda ${ }^{1}$, K. Anwar ${ }^{1}$, Anifah ${ }^{1}$, D. Ray ${ }^{1}$ \\ $\{*$ ljananda@unimed.ac.id $\}$ \\ ${ }^{1}$ Faculty of Education, Medan State University
}

\begin{abstract}
The role of education is very vital to form human beings who are intellectually intelligent and characterized. The current character condition of the Indonesian generation is still a self-fear for this nation for the sake of realizing the desired Golden Generation. The easiest character building is when children are still in elementary school, called the Golden Age, in this period children are more easily formed. Strengthening Character Education in Elementary Schools is very important as the foundation for the cultivation of the nation's character, so that when the time of 100 years of Indonesian independence comes, the generation of gold aspired by the State of Indonesia will be born as expected, the devoted, nationalist Golden Generation, strong, independent, and has a competitive advantage globally. In order to prepare the Golden Generation of 2045, the government strengthens the character of the young generation through Strengthening Character Education. Strengthening Character Education can be done through three approaches, namely class-based, school-based, and community-based.
\end{abstract}

Keywords: Character education, elementary school, gold generation

\section{Introduction}

Indonesia will be heading for the second revival which is the nation's 100-year long journey in 2045. This is one of the reasons for the emergence of Golden Generation 2045 ideas. The golden generation is a generation that is able to compete globally with a comprehensive and superior civilized intelligence. This is the biggest hope of the Indonesian people in 2045 in the effort to realize the golden generation.

The echo of the Indonesian Golden Generation is increasingly echoing across the country and giving a sense of optimism because at the same time Indonesia will experience a demographic bonus where the highest population of productive age is between the ages of children and the elderly. By 2045, Indonesia's demographic bonus is Indonesia's $70 \%$ population in the productive age (15-64 years), while the remaining 30\% are unproductive population (under 14 years and over 65 years) in the period of 2020- 2045 (BKKBN, 2017). Like the two sides of a bonus demographic currency, it can be demographic dividend if the government provides careful and periodic monitoring and handling.

On the other hand, of course this demographic bonus can lead to disaster (disaster demographic) if the demographic bonus is not used properly. Especially social problems such as poverty, low health, unemployment, and high crime rates. To prepare for the golden generation of 2045, the role of education is vital to form human beings who are intellectually intelligent and characterized. Therefore, education needs to change the mindset that can be 
interpreted that education is not only about knowledge transfer but is equipped with character. This academic balance with character needs to be prepared early.

Character is the main element of quality human beings. Sukidi (2005: 4) says that the phenomenon of the life crisis (character crisis) is not solely an intellectual and moral crisis, but a little deeper into the heart of the problem that the moral crisis that almost penetrates our entire life line actually originates and leads to a spiritual crisis. This means that the crisis character is not just losing 18 traits, but character education is far more fundamental, namely the functioning of conscience (SQ).

The current character condition of the Indonesian generation is still a self-fear for this nation for the sake of realizing the desired Golden Generation. How come? Based on data from the Indonesian Child Protection Commission in 2015 that cases of children as perpetrators of violence are increasing. In 2014 there were 67 cases of children who became perpetrators of violence while in 2015 it increased to 79 cases. The case of children as brawlers also increased. In 2014 there were 46 cases, in 2015 there were 103 cases. Meanwhile, the Bali Provincial Commission for the Protection of Regional Children revealed that 253 children in Bali were faced with law throughout 2017 both as victims and as perpetrators, out of which 137 children were perpetrators of crime, theft and involvement of motorcycle gangs.

Child crime data in the previous paragraph shows indirectly the character of the nation's children who have been damaged. The data above shows the alarming condition of the character of the young generation of the Indonesian people. The hope of welcoming the Golden Generation in 2045 is not something that is not just mere discourse. This problem is a very complicated problem that requires handling directly, quickly and accurately.

Talking about character planting is never separated from the world of education. The Ministry of Education and Culture launched the Character Education Movement for all levels of education from elementary school to high school. The easiest character building is when children are still in elementary school, called the Golden Age, in this period children are more easily formed. In addition, elementary school is the beginning of formal education obtained by a child as well as the beginning of his formation. So, planting good character in elementary school age is very important to do.

Based on the background of the above problems, the problem that will be discussed in this article is "What is the Application of Strengthening Character Education in Primary Schools as the Foundation of Indonesian Gold Generation 2045?". The purpose of writing this article is to provide an overview of the application of Strengthening Character Education in Elementary Schools as a Foundation for Forming Indonesian Gold Generation 2045.

\section{Methodology}

\subsection{Strengthening Character Education in Primary Schools}

Implementation of Strengthening Character Education in the nation's generation is carried out in formal education. Elementary School as the most basic formal education in implementing this character education. Strengthening Character Education in Primary Schools is very important as the foundation for the cultivation of the nation's character, so that when the time of 100 years of Indonesian independence comes, the generation of gold aspired by the State of Indonesia will be born as expected, the devoted, nationalist Golden Generation, strong, independent, and has a competitive advantage globally. Robert J. Havigurst (1961) 
argued about the task of individual development, which is a task that appears in a certain period in an individual's life that must be faced, mastered, and resolved properly, if the development task is not completed properly it will impact unhappiness in development next. Havigurst stated that developmental tasks related to character building existed between $6-12$ years (elementary school age), namely the development of a holistic attitude, the development of morals, values, and conscience.

Sutirna [1] states that at the age of 6 years to adolescence boys and girls behave according to what is expected by the group. Moral values or rules are largely determined by the norms in the group environment. At the age of 10 to 12 years children can know the reasons or principles underlying the rules. His ability has developed so as to be able to distinguish various kinds of moral values and connect the concepts of morality regarding honesty, property rights, justice, and honor. While when a child approaches adolescence, the child has developed moral values as a result of his moral experience during elementary school.

Ministry of Education and Culture said character education is a very important key in shaping the child's personality. Besides at home, character education also needs to be implemented in schools and social environments. In essence, education has a purpose to help people become smart and grow into good people. In order to prepare the Golden Generation of 2045, the government strengthens the character of the young generation through Strengthening Character Education. The easiest character building is when children are still in elementary school.

Based on some of the opinions above, it can be concluded that the Strengthening of Character Education is very important to do at the age of elementary school as a strong foundation to form the Golden Generation in 100 years of independent Indonesia. Character building at the age of elementary school becomes the beginning that must be done so that the generation of the nation that will be born into a generation that has religious values, nationalist, independent, mutual cooperation, and integrity.

\section{Result and Discussion}

\subsection{Implementation of Strengthening Character Education}

Strengthening Character Education implementation is not carried out specifically for one subject. Strengthening Character Education can be done through three approaches, namely class-based, school-based, and community-based. Class-based Strengthening Character Education implementation is done by integrating in activities carried out in the classroom. Class-based can be done in several ways, namely:

a. Integrating Strengthening Character Education into The Curriculum

Integrating Strengthening Character Education into the curriculum implies that educators integrate Strengthening Character Education core values into the learning process in each subject. Learning that integrates the main values of the character is intended to foster and strengthen knowledge, instill awareness, and practice the main values of Strengthening Character Education.

b. Strengthening Character Education Through Class Management

Classroom management is an educational moment that places the teacher as an authorized individual and has the autonomy to manage the learning process. Educators have the authority to prepare (before entering class), teach and after teaching, by preparing learning scenarios that focus on the main values of the character. For example: students become 
good listeners or listen when the teacher explains in the classroom (can strengthen the value of mutual respect and tolerance), students raise their hands before asking the teacher and asking questions after being allowed by the teacher (can strengthen the value of mutual respect and trust self), giving sanctions that educate as a consequence and form of responsibility if there is a delay in doing or collecting tasks (can strengthen the value of discipline, responsibility and self-commitment), teachers encourage students to do peer tutoring (can strengthen the value of mutual cooperation, social care, confident, and responsible).

c. Strengthening Character Educationthrough Choices and Use of Learning Methods

Some learning methods that teachers can choose to integrate character education in learning, namely: scientific learning methods, inquiry methods, problem-based learning methods, project-based learning, cooperative learning methods, text-based learning methods.

d. Strengthening Character Education Through Thematic Learning

The education unit designs its own themes and priorities for what character education will emphasize. Strengthening Character Education through thematic learning is learning activities carried out by education units by allocating specific time to teach certain values.

e. Strengthening Character Education through literacy movements

Literacy movement is an activity to hone the ability to access, understand, process, and utilize information critically and intelligently based on the activities of reading, writing, listening, and speaking to develop one's character to be strong, strong and good. Each teacher can invite students to read, write, listen, and communicate carefully, carefully, and precisely about a theme or topic that exists in various sources, both books, newspapers, social media, and other media.

\subsection{Strengthening Character Education Culture Based}

Strengthening Character Education based on school culture focuses on habituation and cultural formation that represents the main values of Strengthening Character Education that are the priority of education units. This habituation is integrated in all activities in the school which are reflected in the conducive atmosphere and school environment. School culturebased Strengthening Character Education begins with determining the main value of Strengthening Character Education, namely the school determines the main values that will be the focus in developing character building and strengthening in the school environment. The selection of key values is discussed, discussed, and dialogue with all school stakeholders (principals, educators, education staff, school committees, and students). Steps for implementing culture-based Strengthening Character Education in schools can be carried out by:

a) Arrange a daily/weekly schedule

The education unit can arrange a daily/weekly activity schedule to strengthen the main Strengthening Character Education values that have been chosen as a habituation and integrated strengthening effort.

b) Evaluation of school regulations

Every educational institution is obliged to make corrections and evaluations of various regulations that they have and harmonize with the main values of Strengthening Character Education who want to be directed. One example of a regulation that must be evaluated is the discipline regulation regarding illness, permit, and negligence, the application of minimum completeness criteria policy, and regulations related to cheating activities. 
c) Development of school traditions

The education unit can develop Strengthening Character Education based on school culture by strengthening the traditions that are already owned by the school.

d) Development of kokurikuler activities

The kokurikuler activity is carried out through a series of assignments that are in accordance with the target of achieving the competence of each subject that is relevant to intracuricular activities. The types of activities are in the form of tasks, both individually and in groups. For example, it can take the form of project activities, research, practicum, observations, interviews, art exercises, and sports, or other productive activities.

e) Extracurricular (compulsory and optional)

Strengthening the main values of Strengthening Character Education is made possible through extracurricular activities. There are two types of extracurricular activities, namely compulsory extracurricular (scout education) and choice extracurricular (according to the extracurricular developed by each education unit). All extracurricular activities developed must contain and confirm the character values developed in each form of activity carried out.

Community Based Strengthening Character Education Various forms of collaboration and collaboration between communities and education units outside of school are needed in strengthening character education. The forms of collaboration include:

(a) Museum-based learning, cultural heritage and art studios.

(b) Mentoring with local artists and cultural observers.

(c) Inspiration class.

(d) On-air radio broadcast program.

(e) Collaboration with television media, newspapers and magazines.

(f) Literacy movement.

(g) Digital literacy.

(h) Collaboration with universities; Lecturer Research.

(i) Cooperation with religious communities.

\section{Conclusion}

Education is closely related to the golden generation of Indonesia because education is the key to bringing reliable human resources and can change attitudes and increase one's knowledge.

The Indonesian gold generation is the current generation that is provided for future generations in making Indonesia a more developed country. To be able to accompany other developed countries, we need to prepare a golden generation of Indonesia by strengthening character education for students through formal education and as early as possible so that Indonesian education products will be born, namely students with character, devotion, toughness and global competitiveness.

\section{Acknowledgements}

This work is supported by Ministry of Higher Education, Malaysia, Grant FRGS - 900100569 


\section{References}

[1] Sutirna, Perkembangan \& Pertumbuhan Peserta Didik. Yogyakarta: Penerbit Andi, 2013.

[2] Gunarsa, S. D. (2012) Dasar \& Teori Perkembangan Anak. Jakarta: Penerbit Libri.

[3] Darman, R. A. (2017) 'Mempersiapkan Generasi Eas Indonesia Tahun 2045 Melalui Pendidikan Berkualitas', Jurnal Edik Informatika, 3(2), pp. 73-87.

[4] Judiani, S. (2010) 'Implementasi pendidikan karakter di sekolah dasar melalui penguatan pelaksanaan kurikulum', Jurnal Pendidikan Dan Kebudayaan, 16(9), pp. 280-289.

[5] Kementerian Pendidikan dan Kebudayaan (2017) Konsep dan Pedoman Penguatan Pendidikan $\begin{array}{lllll}\text { Karakter, Kemendikbud, Jownloaded } & \text { Jul }\end{array}$ $<$ http://cerdasberkarakter.kemdikbud.go.id/content/modul_dan_buku_saku> http://bankdata.kpai.go.id(diakses pada tanggal 05 juli 2018)

[6] Divianta, D. (2017) 137 Anak di Bali Jadi Pelaku Kejahatan, 116 Jadi Korban, Liputan6, Accessed Jul 5, 2018, <https://www.liputan6.com/regional/read/3203700/137-anak-di-balijadi-pelaku-kejahatan-116-jadi-korban> 